\title{
YAŞAM DOYUMU VE TÜKENMIŞLIK; ÖĞRETMENLER ÜZERİNE BİR ARAŞTIRMA
}

\section{LIFE SATISFACTION AND BURNOUT; A RESEARCH ON TEACHERS}

\author{
Mustafa SOBA ${ }^{1}$, Ali BABAYİĞİT², Ebru DEMİR ${ }^{3}$
}

$\ddot{O}_{z}$

Milletlerin ruh ve karakterlerinin şekillenmesinde etkin rol oynayan, milletlerin varlığını devam ettirmesi, ayakta durabilmesi, güçlü ve müreffeh bir şekilde geleceğini garanti altına alabilmesi için kendilerini yetiştirecek, hayata hazırlayacak eğitimcilere ve öğretmenlere ihtiyaç duymaktadırlar. Öğretmenlik mesleği toplumsal hayatın bir ürünü olmasının yanı sıra içinde bulunduğu toplumun kültürünü, değerlerini gelecek nesillere aktaran ve bununla birlikte toplumun gelişmesini ve çağdaşlaşmasını sağlamaktadır. Önemli bir mesleği icra eden öğretmenlerin kendilerinden beklenilen performansları gösterebilmeleri psikolojik ve sosyal açıdan kendilerini iyi hissetmelerine bağlıdır. Bu bakımdan öğretmenlerin mesleklerini icra ederken karşılaşmış oldukları en önemli sorunların başında tükenmişlik gelmektedir. Bu çalışmada Antalya'nın Alanya ilçesinde Milli Eğitim Bakanlığı'na bağll ilkokul, ortaokul ve lise dengi okullarda görev yapan öğretmenlerin tükenmişlik düzeyleri ve yaşam doyumları incelenmiştir. Araştırmada Maslach Tükenmişlik ölçeği ve Yaşam Doyum ölçeği kullanılmıştır. Elde edilen verilerin geçerlilik ve güvenirliklerin tespit edilmesi amacıyla faktör analizi yapılmıştır. Ayrıca boyutlar arasındaki ilişkileri ve etkileri belirlemek amactyla korelasyon ve regresyon analizi yapılmış ve demografik değişkenler $t$ testi ve Anavo analizine tabi tutulmuştur. Araştırma sonucunda ögretmenlerin "duygusal tükenme" ve "duyarsızlaşma" eğilimlerinin düşük, "kişisel başarl" eğilimlerinin ise ortalamanin üzerinde biraz yüksek olduğu görülmüş̧ür. Ayrıca ögretmenlerin yaşam doyum düzeylerinin orta düzeyde olduğu saptanmıştır.

Anahtar Kelimeler: Tükenmişlik, Yaşam Doyumu

\section{Abstract}

The Nations need educators and teachers, who play an active role in shaping of spirit and characters of nations, continuing their presence, keeping up, guaranteeing the future in a strong and prosperous way, educating them and prepare for life. Besides being a product of social life, teaching profession transfers the culture, values of society to next generations and it ensures the development and modernization of society.For teachers, who perform a valuable job, ability of showing expected performances depends on feeling psychologically and socially well. In this regard, burnout is the most important problem that teachers encounter

\footnotetext{
${ }^{1}$ Doç. Dr. Mustafa SOBA, Uşak Üniversitesi, İşletme Bölümü, mustafa.soba@usak.edu.tr

${ }^{2}$ Ali BABAYİĞİT, Uşak Üniversitesi, İşletme Bölümü, Doktora Öğrencisi, babayigitali03@gmail.com

${ }^{3}$ Ebru DEMIR, Uşak Üniversitesi, İşletme Bölümü, Yüksek Lisans Öğrencisi, ebruudmr@live.com
} 
while they perform their job. In this study, levels of burnout and life satisfactions of primary, secondary, high school teachers and their equivalents working for the Ministry of National Education in the town of Alanya in Antalya have been examined. Maslach Burnout Inventory and Life Satisfaction Scale have been used in the study.Factor analysis has been carried out to determine the validity and reliability of the obtained data. Also, correlation and regression analysis have been carried out to determine the relations and effects between the dimensions and demographic variables have been put to t test and Anova analysis. As a result of survey, it has been found out that teachers' "emotional exhaustion" and "depersonalization" tendencies are low but their "personal success" tendencies are slightly higher than average. In addition, it has been determined that life satisfaction levels of teachers are at medium level.

Keywords: Burnout, Life Satisfaction

\section{GİRIŞ̧}

Çalışma ve iş hayatı bireylerin yaşamının merkezinde rol oynayan önemli alanlardan biridir. Bireyler günlük hayatlarında zamanlarının çoğunu iş ve işle ilgili faaliyetleri yaparak veya planlayarak geçirmektedirler. Diğer yandan son yıllarda teknoloji, bilişim ve sosyal alanlarda yaşanan değişimler, bireylerin günlük yaşamını ve çalışma yaşamını etkilemekte ve bireylerin birçok sorunla karşı karşıya kalmasına neden olmaktadır. Ayrıca toplumsal rollerde meydana gelen farklılaşmalar, bireyler arasında yaşanan anlaşmazlıklar, çalışma ortamlarında rekabetin yükselmesi, bireylerin kendilerini kanıtlama çabası, beklenti ve ihtiyaçların artması gibi unsurlar bireylerin ruh ve beden sağlığını tehdit etmekte ve günümüzün en büyük sorunlarından birisi olan tükenmişlik fenomenini ortaya çıkarmaktadır. Yapılan araştırmalar, tükenmişliğin insanlarla birebir ilişki içerisinde olunan meslek gruplarında daha fazla yaşandığını ortaya koymakta (Çapri, 2006:63) ve özellikle insanlara karşı duyulan sorumluluğun, nesnelere karşı duyulan sorumluluktan daha fazla olması nedeniyle bu kişilerde tükenmişlik riskinin daha yüksek olduğunu göstermektedir (Ardıç ve Polatçı, 2009:22). Öğretmenlerin genel olarak diğer meslek gruplarına nazaran daha fazla stres altında olmaları eğitim ve öğretim alanında yaşanan öğrenci-öğretmen ve öğretmen-aile çatışmaları, yaşanan disiplin sorunları, fiziki koşullardaki yetersizlik, toplumsal eleştiriler, sosyal ve politik baskılar gibi sorunlar (Cemaloğlu ve Şahin, 2007:466) nedeniyle öğretmenlerin yaşam doyumu ve tükenmişlik düzeylerinin tespitini gerekli kılmaktadır. Zira öğretmenlerin yaşam doyumu ve tükenmişlik seviyeleri; onların verimlilik ve performansıyla yakından ilgilidir.

\section{TÜKENMİSLIKK}

Bireylerin sahip oldukları işleri ile olan ilişkileri ve bu ilişkinin ters gitmesi halinde ortaya çıkan zorluklar, modern çağın önemli bir olgusunu ortaya çıkarmıştır. Bu olgu için kullanılan tükenmişlik (burnout) teriminin, 1970'lerde Amerika'da, özellikle de insanlara hizmet veren işlerde çalışan bireylerde ortaya çıktı̆̆ görülmektedir. Tükenmişlik, insanların iş ilişkilerindeki karmaşaya dayandırılmıştır ve bu ilişkiye bazı yeni bakış açıları getirmiştir. Bu yönüyle işyerlerindeki bireylerin ilişkilerindeki gerçekleri ortaya çıkarma gücünü elinde tutan tükenmişlik terimi, hem önemli hem de tartışmalı bir araştırma alanıdır (Maslach vd., 2001:398). Konuyla ilgili ilk çalı̧̧malar bir alternatif sağlık tedavi merkezinde psikiyatrist olarak çalışan Freudenberger (1975) ve iş hayatındaki duyguları inceleyen sosyal psikolog Maslach (1976) tarafından yapılmıştır (Maslach vd., 2001:399). Bu çalışmaların ardından günümüze kadar tükenmişlikle ilgili birçok araştırma yapılmış ve birçok tanım geliştirilmiştir. Tükenmişlikle ilgili ilk makaleyi yazan ve kavramı ilk kez tanımlayan Freudenberger'e göre tükenmişlik, enerji, güç ve kaynaklar konusundaki aşırı talepten kaynaklı olarak kişinin 
başarısız olması, yıpranması ve bitkin düşmesi olarak tanımlanmıştır (Freudenberger, 1974:159). Ergin'in (1992) tanımına göre ise tükenmişlik, bireylerin çalışma hayatında rastladıkları insanlara karşı duyarsızlaşmaları, duygusal olarak tükenmiş hissetmeleri ve şahsi başarı ve yeterlik hislerinin azalmasıdır (Ergin 1992). Bir diğer tanıma göre kişinin iç dünyasına çekilmesi, çevresine karşı ilgisini kaybetmesi ve yoğun bir şekilde başarısızlık hissi yaşamasıdır (Maraşlı, 2005:29). Altay ve arkadaşlarına (2010) göre tükenmişlik sinsice gelişen duygusal, zihinsel ve fiziksel yorgunluğu ifade eder ve duygusal beklentilerin aşırı olduğu işlerde uzun süreli çalışmayla ortaya çıkar (Altay vd., 2010:10). Tükenmişlikle ilgili en yaygın ve kabul görmüş tanım ise Maslach’a (1981) aittir. Maslach, tükenmişliği "işinden dolayı sürekli diğer bireylerle yüzyüze çalışan ve yoğun duygusal taleplerle karşılaşan kişinin fiziksel bitkinlik, yorgunluk, çaresizlik ve umutsuzluk yaşayarak işe, yaşama ve diğer bireylere karşı olumsuz tutumlar geliştirdiği bir tür sendrom” olarak ifade etmektedir (Maslach ve Jackson, 1981:99). Yapılan tanımların ortak noktası tükenmişlik hissinin yaşanan deneyimlerle birlikte gelişen ve pekişen olumsuz duygu ve tutumlar olmasıdır. Bu duygu ve tutumlarla birey, olumsuzluk yaşadığı ortamdan kendini geri çekmektedir.

Tükenmişliği 1981 'de insanlarla yüzyüze iş yapan bireyler arasında sıklıkla meydana gelen duygusal tükenmişlik ve sinizm sendromu olarak tanımlayan Maslach ve arkadaşları tükenmişliği, baskın tükenmişlik (overwhelming exhaustion), sinizm yani duyarsızlaşma (cynicism or depersonalization) ve başarı veya etkinlik azalması (reduced efficacy or accomplishment) olmak üzere üç temel boyutta ele almıştır (Maslach vd., 2001:399; Maslach ve Jackson,1981:99). Baskın tükenmişlik, tükenmişliğin temel kişisel stres boyutunu temsil eder ve kişinin duygusal ve fiziksel kaynaklarının tükenmişliğini, verecek bir şeyi kalmadığını ifade eder (Maslach vd., 2001:399; Maslach ve Jackson,1981:99; Cordes vd.,1997:687). Bu ilk aşamada birey yoğun taleplerle karşılaşır ve duygusal kaynaklarını tüketir. Kendisini hem fiziksel hem duygusal açıdan aşırı yıpranmış ve yorulmuş hisseden kişi, işine odaklanamaz, karşılıklı ilişki kurarak iş yaptığı bireylere karşı kendisini daha önce olduğu kadar sorumlu hissetmez (Ardıç ve Polatc1, 2009:23). Sürekli devam eden problemlerle karş1laşan çalışanlar, duygusal yorgunluklarını değişik şekillerde dışa vururlar ve sorunlarla başa çıkabilmek için duygusal isteklerle karşılarına çıkan insanlarla aralarına mesafe koyarlar (Cordes vd.,1997:687). Sinizm veya duyarsızlaşma, tükenmişliğin kişiler arası bağlam boyutunu temsil eder ve işin çeşitli negatif, duygusuz veya aşırı kişisel yönlerini ifade eder (Maslach vd. 2001,399; Maslach ve Jackson,1981:99). İnsanlarla etkileşimlerini duyarsızlaştıran çalışanlar, yaşadıkları sorunlarla ve kendileriyle iletişime geçen insanlarla baş etmek için duygusuz, insani iyiliğe inanmayan veya insanlarla bağlantısız bir yol benimserler ve böylelikle kendilerine duygusal bir tampon oluştururlar. Duyarsızlaşma organizasyona karşı müşteri, iş arkadaşı, astları gözetmeksizin alaycı, bağımsız ve duygusuz davranış ile kendini gösterir (Cordes vd.,1997:687-689). Wright ve Bonett'e (1997) göre duyarsızlaşma, müşteri merkezli bir durumla savaşmayı, bireyselliği kullanmayı ve mevcut kaynakları korumayı ifade eder (Wright ve Bonett, 1997:493).

Azalmış etkinlik veya başarı bileşeni tükenmişliğin öz değerlendirme boyutudur. Birey işten ayrılma, etkisizlik duygusu ve başarı eksikliği, kendini yetersiz hissetme, verimlilik eksikliği ve kendini beceriksiz görme gibi duyguların gözlemlendiği yani bireyin kendisini olumsuz değerlendirme eğilimi içerisine girdiği bir boyuttur (Maslach vd., 2001:399; Maslach ve Jackson,1981:99; Ardıç ve Polatçı, 2009:23). İnsanlarla iletişime daha az zaman ve enerji ayıran çalışan, zamanla işinde kişisel başarı düşmesi hissetmeye başlar ve insanlarla olan iletişiminin etkinliğinde ve başarısında yetersizlik duygusuna kapılır (Cordes vd.,1997:687). Çalış1lan işin özellikleri de stres ve tükenmişliğe etki eden önemli bir faktör olarak karşımıza çıkmaktadır. Çalışma hayatında 
bireylerle sadece verici yönde bir iletişime girmek zorunda kalan insanlar, verdikleri kadar alamadıkları durumlarda, zamanla tükendiklerini ve verecek bir şeyleri kalmadığını hissetmeye başlarlar (Maraşlı, 2005:28). Özellikle tükenmişlik hissi, insanlara yüz yüze hizmet vererek yoğun ve sürekli ilişki içinde çalş̧an doktor, hemşire, öğretmen, psikolog ve polis gibi meslek mensuplarında daha sık görülen bir durumdur (Altay vd., 2010:11).

Yukarıda değinildiği gibi insanlarla birebir ilişki çerçevesinde çalışan, insanlara hizmet veren bireylerde tükenmişlik daha kolay gelişebilmektedir. Öğretmenlik de yüz yüze ve doğrudan hizmet veren ve hizmet verilen paydaş grubunun beklentilerinin yüksek olduğu meslek gruplarındandır. Dolayısıyla öğretmenlerden gerçekleştirmeleri beklenen birçok talep ve beklentiler mevcuttur. Eğitim verdikleri bireylerin sürekli ve hızlı bir şekilde değişen teknoloji-yoğun topluma uyum sağlaması ve hizmet verdikleri grubun çeşitli sorunları ile meşgul olmaları beklenen öğretmenler de yoğun iş stresi sonucu tükenmişlik yaşayabilmektedirler (Cemaloğlu ve Şahin, 2007:466). Öğretmenlerin tükenmişlik düzeyleri arttıkça öğrencilere ve velilere karşı tutumlarının daha umursamaz, acımasız ve alaycı olduğu görülmektedir. Öğretmenin bu tavrıyla birlikte sınıfta rahatsız edici bir ortam oluşabilmekte ve verilen eğitimin kalitesinin de düştüğü gözlemlenmektedir (Maraşl1, 2005:29). Öğretmenlik de insanlara doğrudan ve yüz yüze hizmet veren, yoğun stres altında çalışan bir meslek olması nedeniyle bu meslekte tükenmişliğin kavramının tanımlanması ve önlenmesi gerekmektedir. Bunun için de öğretmenlerin hislerini açıkça belirtebilecekleri, geri bildirim, danışma ve yardım sağlayabilecekleri bir sistemin kurulması gerekmektedir (Dolunay, 2002:52).

Bireyin yaptığı işten doyum alması, yaşam doyumunda ve üretkenliğinde önemli bir faktör olduğu bilinmektedir. $\mathrm{Bu}$ bağlamda bireyin yaşam doyumuna pozitif ya da negatif yönde etki yapan faktörler belirlenerek, kişinin daha fazla doyum ve daha az tükenmişlik yaşaması için gerekli düzenlemeler yapılabilir (Ünal vd., 2001:114). Tükenmişlik duygusunun hissedilmediği, bireylerin iş tatmininin yüksek olduğu bir kurumda, verilen hizmet kalitesinin de yüksek olacağı şüphesizdir. Tükenmişlik sendromu, nadir görülen bir durum değildir, aksine iş hayatındaki kişilerin \%80'inin çalışma hayatında karşılaştığ bir durumdur. Yavaş yavaş ve farklı faktörlerle gelişerek ortaya çıkan bu durum, kişinin psikolojik durumunu bozarak iş, aile ve sosyal hayatını negatif etkilemektedir (Güdük vd., 2005:169). Öğretmenlerde gözlemlenen tükenmişlik yabancı literatürde yoğun bir biçimde incelenmesine karşın, ülkemizde bu konu özellikle 90'ların ortalarından itibaren ele alınmaya başlanmıştır (Gündüz, 2005:154).

\subsection{Tükenmişliğe Etki Eden Faktörler ve Belirtileri}

Tükenmişliğin ortaya çıkmasında birçok faktör etken olabilmektedir. Bu faktörler bireysel, sosyal ve örgütsel faktörlerden veya bu faktörlerin birleşiminden kaynaklanabilmektedir. Tükenmişliğin ortaya çıkmasında etkili olan bireysel, sosyal ve örgütsel birçok faktör, tükenmişliğin daha iyi tanınması ve tükenmişlikle başa çıkılabilmesi açısından oldukça önemlidir (Ardıç ve Polatcı, 2009:23). Kişinin tükenmişlik yaşayıp yaşamayacağı ya da tükenmişliği ne düzeyde yaşayacağı yaş, cinsiyet, deneyim, eğitim seviyesi gibi bireysel faktörlerden etkilenebildiği gibi çalışma süreleri, yöneticiler, sosyal destek, iş doyumu, çalışma şartları, hizmet verdiği bireylerin özellikleri gibi değişik örgütsel faktörlerden de etkilenmektedir (Kayabaşı, 2008:193). Bireyin sahip olduğu kişisel özellikleri bazen tükenmişliği tetikleyebildiği veya arttırabildiği gibi bazen de tükenmişliğin etkilerini azaltabilmektedir. Cinsiyet, yaş, eğitim, medeni durum, çalışma süresi, kişilik ve beklentiler bireyin tükenmişlik durumuna etki eden bireysel özelliklerdir (Ar1 ve Bal, 2008:136). Ergin'in (1992) doktorlar ve 
hemşireler üzerinde yaptığı bir araştırmada, kadınların erkeklere oranla daha fazla duygusal tükenme yaşadığı; evlilere kıyasla bekârlarda duygusal tükenme ve duyarsızlaşmanın daha fazla olduğu; kıdemli çalışanlara kıyasla yeni işe başlayanların daha fazla duygusal tükenme yaşadığı gözlemlenmiş; cinsiyetin, medeni durumun ve çalışma süresinin duygusal tükenmişlikte önemli birer etken oldukları ortaya konmuştur (Ergin, 1992). Ayrıca duygusal tükenmişlikte aile durumu ve sosyal destek gibi sosyal faktörlerin de oldukça etkili olduğu görülmektedir. Tatmin edici bir aile yaşamına sahip olan, sosyal çevresi ile sorunlarını paylaşarak çözüme ulaştıran bireylerde tükenmişliğin azaldığı bilinmektedir (Arı ve Bal, 2008:136).

Tükenmişliği etkileyen bir diğer faktör de iş doyumudur. Bireylerin çalıştıkları mesleklerine ve kurumlarına ilişkin beklentileri, tükenmişliği tetikleyici veya azaltıcı özelliğe sahip olduğu görülmektedir. Yaş, cinsiyet, eğitim düzeyi gibi bireysel etkenlerin yanında işin içeriği, ücretlendirme, çalışma şartları, çalışma süresi, iş yükü, örgütsel işleyişteki aksaklıklar, iş yeri adaletsizliği, personel eksikliği vb. kurumsal ve çevresel faktörlerin iş doyumuna etki ettiği belirtilmektedir (Güllüce ve İşcan, 2010:9). Özellikle iş yaşamında yüksek performans sergileyen bir işgören, bu gayretinin karşıllığına denk bir ödül almadığı ya da takdir görmediği durumda, bunu kabullenemezse tükenmişlikle karşı karşıya kalacağı ve sürekli bir ümitsizlik ve olumsuzluk yaşayacağ1 vurgulanmaktadır (Maraşl1, 2005:28). "Yapılan işin niteliği, iş ve iş yükü, çalıştı̆̆ örgütün özellikleri, iş gerilimi, hizmet verilen kişilerin doğrudan bakımına ayrılan zaman miktarı, meslektaşlardan ve örgütten sağlanan desteğin yetersizliği, ilerleme firsatındaki kısıtlllık, rol belirsizliği, ödül beklentisinin karşılanmaması, mesleğin ilerlemeye açık olmaması, örgütsel başarı değerlemesindeki belirsizlik, iş ilişkilerinin karmaşıklık derecesi, iş aralarının olup olmaması, işgörenlerin toplantı ve kararlara katılım olanağı ve sıklığı, ulaşım şartları, örgüt yöneticilerinin liderlik tarzı, iş ortamındaki iletişim, yeterli araç-gerece sahip olmama, örgütün yapısal sorunları vb. iş ve örgütle ilgili nedenler" tükenmişliğe verilen geniş ölçekli örnekler olarak karşımıza çıkmaktadır (Kılıç ve Seymen, 2011:50). Tükenmişlik, kişiden kişiye belirti ve dereceleri farklılık gösteren boyutlarda ortaya çıktığı (Freudenberger, 1974:160) ve bu belirtilerin göz ardı edilmesi durumunda tükenmişliğin ilerlemesine ve baş edilemez hale gelmesine sebep olacağından, tükenmişlik durumlarının iyi teşhis edilerek zamanında gerekli tedbirlerin alınması gerektiği vurgulanmaktadır (Ardıç ve Polatcı, 2009:29).

\subsection{Tükenmişliğin Sonuçları}

Tükenmişlik ve iş, işe devamsızlık, işten ayrılma ve iş değiş̧irme niyeti gibi çeşitli yönlerden ilişkilendirilmektedir. Bununla birlikte işine devam eden çalş̧anlarda tükenmişlik, üretkenliğin ve iş verimliliğinin düşüşüne ve organizasyona bağlıllğın azalmasına, organizasyon içerisinde iş arkadaşlarına negatif yaklaşmaya, iş görevlerinin aksatılarak kişisel çatışmalar yaşanmasına neden olduğu belirtilmektedir (Maslach vd.,2001:406). Tükenmişlik yaşayan bireyde işten ayrılma, mesleki doyumsuzluk, evlilik ve aile hayatında problemler, uykusuzluk, alkol ve ilaç kullanımında artış gibi problemler görülebilmektedir (Ergin, 1992). İş yaşamında ortaya çıkan stres, bireyin çalışma hayatını, aile hayatını, sosyal hayatını, bireylerle olan ilişkilerini, üretkenliğini, verimliliğini ve uyumunu olumsuz yönde etkileyebilmektedir (Ceyhan ve Siliğ, 2005:44). Sağlıkla ilgili sonuçları açısından tükenmişliğin stresle yakından ilgili olduğu herkesçe bilinmektedir. Ancak uzun süreli stres fizyolojik sonuçlar doğururken, tükenmişliğin ruh sağlığı ile olan ilişkisi çok daha karmaşık olduğu vurgulanmaktadır (Maslach vd., 2001:406). Öğretmenlerin diğer meslek gruplarına kıyasla daha çok strese maruz kalmaları nedeniyle tükenmişlik duygusundan en çok muzdarip olan meslek mensupları arasında öğretmenlerin önemli bir yer tuttuğu kabul edilmektedir. Öğretmenlerin karşılaştıkları sorunlar, bu bireylerin işe 
karşı olumsuz tutum sergilemesine, iş devamsızlıklarına hatta fiziksel ve ruhsal problemlere sebebiyet vererek eğitim ortamına ve öğrencilere, dolayısı ile tüm topluma da olumsuz bir şekilde etki ettiği belirtilmektedir (Kayabaş1, 2008:193).

\section{3. İŞ VE YAŞAM DOYUMU}

Doyum; bireyin beklentilerinin, ihtiyaçlarının, arzu ve taleplerinin karşılanmasıdır. Yaşam doyumu bireyin bütün yaşamını ve yaşamının tüm boyutlarını kapsar (Yılmaz vd., 2010:93). Yaşam, bireyin işte ve iş dışında geçirdiği zamanın tümüdür. Kişi iş dışında geçirdiği zamanı ailesi ile birlikte, ailesi ve ev yaşamı için gerekli işleri yaparak, kendisine vakit ayırarak veya arkadaşları ile birlikte geçirir. Yaşam doyumu ise bireyin tüm bu zamanlarda yani iş ve iş dışı zamanda yaşama karşı gösterdiği duygusal tutumudur (Dikmen, 1995:117). Bireyin yaşama dair beklentileri ve bu beklentilerin karşılanıp karşılanmaması bireyin yaşam doyumunu ya da yaşam doyumsuzluğunu ifade eder. Bir bireyin kendisine dayatılan standartlardaki yaşam durumu ile muhtemel standartları kıyaslaması ve şartlarının bu standartlarla eşleşme derecesi yaşam doyumu olarak belirtilebilir. Yaşam doyumu, kişinin kendi belirlediği kriterleri ile hayatına ilişkin yaptığ 1 bilinçli bilişsel yargıdır (Pavot ve Diener, 1993:164). Avşaroğlu vd.'ne (2005:118) göre yaşam doyumu, bireylerin yaşam örüntüleri ve kendi yaşam standartları ile alakalı proseslerin bütünüdür. Kişinin hayatında iş, önemli bir yere sahiptir ve gelir sağlayıcı tek unsur olarak kabul edildiğinde önemi her geçen gün artmaktadır (Yılmaz vd., 2010:92). İş doyumu, bireylerin işlerinden memnun olup olmadığı ile tanımlanmaktadır. İşinden memnun olan çalışanların iş doyumlarının yüksek, işinden memnun olmayan çalışanların ise iş doyumlarının düşük olması beklenmektedir (Ertürk ve Keçecioğlu, 2012:42). İş doyumu, çalışan bireylerin işlerine karşı olan tutumları, duygusal tepkileridir. İş doyumu da genel doyum kavramı gibi gereksinimlerin giderilmesi ile ilişkilidir (Avşaroğlu vd., 2005:117). Eğinli (2009), çalışan bireylerin işlerine yönelik tutumlarını iş ve çalışmaya yönelik tepki olarak açıklamıştır. İş ve çalışmaya yönelik bu tutumlar olumlu olduğunda iş doyumu, işinden memnun olma olarak ifade edilirken, olumsuz tutumlar iş doyumsuzluğu ya da işinden memnun olmama şeklinde açıklanmaktadır. Çalışan bireylerin iş doyumsuzluğu yaşaması geç gelmesine, devamsızlık yapmasına, iş değiştirmesine, performansının düşmesine neden olmaktadır. Bireylerin iş doyumu ya da iş doyumsuzluğu yaşaması, işyerini de olumlu ya da olumsuz yönde etkilemektedir (Eğinli, 2009:35-36).Çalışan bireylerin işlerine karşı olan bu algıları yaşam algılarını, dolayısıyla da yaşam doyumunu etkilemektedir (Yılmaz ve Sünbül, 2009:174).Bireyin yaptı̆̆ işten aldığı doyum, yaşam tatminine etki etmektedir. Yaşam doyumuna olumlu ya da olumsuz etki eden faktörler belirlenerek, bireyin yaşam doyumunu artırmak ve daha az tükenme yaşamasını sağlamak için gerekli düzenlemeler yapılabilir (Ünal vd., 2001:114). Tükenmişliğin iş ve yaşam doyumu ile ilişkili olduğu açıktır. İş doyumunun elde edilemediği ortamlarda yaşam doyumu ve tükenmişlik de olumsuz etkilenmektedir (Avşaroğlu vd., 2005:117). Çalışanların işten, ücretten, güvenlikten, sosyal çalışma şartlarından, denetimden, gelişme olanaklarından duydukları doyum, iş doyumunu olumlu yönde etkiler (Eğinli, 2009:36). Eğitim politikalarında sıkça değişiklik yapılması, ekonomik sıkıntılar, iş yükü, öğrencilerin ve ailelerin ilgisizliği, okulda yaşanan sorunlar gibi sebeplerle çalışanlar, yetersizlik, doyumsuzluk ve tükenmişlik yaşarlar (Telef, 2011:92). Öğretmenlerin ekonomik durumları, mesleki pozisyonları, çalıştıkları yer ve çevre şartları ve beklenti seviyeleri, onların yaşam doyumlarını etkilemektedir. Böylece öğretmenlerin iş doyum ve mesleki tükenmişlik düzeyleri, yaşam doyumlarını da etkilemektedir (Avşaroğlu vd., 2005:118). 


\section{4. İŞ / YAŞAM DOYUMU VE TÜKENMISSLLIK İLISŞKISİ}

Bireylerin iş yaşamlarında ve iş dışı yaşamlarında yaşadıkları doyum veya doyumsuzluk yaşam doyumunu meydana getirmektedir. Yaşam doyumunun tükenmişlikle karşılıklı bağımlılık ilişkisi göze çarpmakta ve tükenmişliğin iş ve yaşam doyumu ile ilişkili olduğu açıktır. Dolayısıyla iş doyumunun elde edilemediği ortamlarda yaşam doyumu ve tükenmişlik de olumsuz etkilenmektedir (Avşaroğlu vd., 2005:117). Tükenmişliğin yaşam doyumu ve iş doyumu ile doğal ve döngüsel bir ilişkisinin var olması nedeniyle yaşam doyumu stres, artan beklentiler, ihtiyaçların karşılanmaması vb. nedenlerle düşen bireyler, tükenmişliğe sürüklenmektedir. Kısacası tükenmişlik, bireylerin yaşam ve iş doyumunu negatif yönde etkileyen önemli bir faktördür (Örkün, 2011:18; Eroğul ve Örkün, 2012:326). Yoğun iş temposu, her gün daha fazla mesleki yeteneğe ihtiyaç duyulması, işveren beklentisini karşılamakta yaşanan stres, işlerin zamanında yetişmemesi vb. sıkıntılar bireyin işine karşı duyarlılığının yok olmasına ve iş doyumunda düşüşe sebep olduğu belirtilmektedir (Okutan, 2013:2). Birey iş yaşamında yaşadığı doyumsuzluğu zaman zaman yaşamının diğer alanlarına da yansıtabilmektedir. İş doyumsuzluğu yaşam doyumsuzluğunun tek ve temel nedeni olmasa da; iş ve iş dış1 yaşam bütününden oluşan yaşam doyumunu negatif yönde etkileyebilmektedir. Buna karşın işinden fazla doyum elde elden bireylerin daha fazla yaşam doyumu sağlamaları beklenen bir sonuçtur. Diğer yandan iş dışı yaşam kalitesi, yaşam doyumunu etkileyen bir diğer faktördür. Yaşam kalitesi, aile yaşantısı, sosyal hayat, ekonomik koşullar, fiziksel özellikler gibi bireyin yaşam doyumuna etki eden birçok faktörü kapsamaktadır (Çeçen vd., 2012:1079). İş ve iş dış1 yaşam bütünlüğünden oluşan yaşam doyumu, tüm bu faktörlerden etkilenmektedir. Bireylerin tükenmişlik yaşamasında etkili olan faktörler incelendiğinde, yaşam doyumuna etki eden faktörlerin tükenmişliğe de sebebiyet verdiği açıkça görülmektedir. Benzer faktörlerin etkisiyle doyumsuzluk yaşayan birey, tükenmişliğe sürüklenebilmektedir. Susan ve Sheridan'a göre doyumsuzluğa neden olan etkenler tükenmişliği ortaya çıkarmaktadır (Oruç, 2007:17). Yaşamdan duyulan doyumsuzluğun tükenmişliği tetiklediği gibi, tükenmişlik de yaşam doyumunu negatif yönde etkilemektedir. Ergin (1992), baskın bir şekilde yaşanan tükenmişlik duygusunun birçok olumsuz sonuçla birlikte doyumsuzluğa sebebiyet verdiğine dikkat çekmiştir.

\section{YÖNTEM}

\subsection{Araştırmanın Amacı}

Araştırmanın amacı, Antalya'nın Alanya ilçesinde ilkokul, ortaokul ve lise dengi okullarında görev yapan öğretmenlerin tükenmişlik düzeylerinin yaşam doyumları üzerindeki etkisini belirlemeye yöneliktir. Öğretmenlerin tükenmişlik ve yaşam doyum düzeylerinin demografik özelliklere göre farklılık gösterip göstermediklerinin incelenmesi ise araştırmanın diğer ikincil amacıdır.

\section{2. Örneklem}

Araştırmanın evrenini Alanya'daki Milli Eğitim Bakanlığına bağlı resmi okullar oluşturmaktadır. Alanya Milli Eğitim Müdürlüğ̈̈ne bağl 6 anaokulu, 69 ilkokul, 60 ortaokul ve 27 lise de görev yapan toplam 3.183 öğretmen oluşturmaktadır. Evreni oluşturan bu rakamı temsil gücüne sahip örneklem grubunu belirlemek amacıyla Baş (2006:45) tarafından önerilen örneklem hesaplama yöntemi kullanılmıştır. Gerçekleştirilen örnekleme hesaplaması sonucunda toplam 386 kişi ile anket uygulaması gerçekleștirileceği sonucuna ulaşılmıştır. Tüm okullarda anket uygulamasının yapılmasının zorluğu ve ulaşım imkânlarının kısıtlı olması sebebiyle 18 okula ulaşılmıştır. Toplamda 500 anket dağıtılmış geri dönüşümü sağlanan 410 anketten 12 tanesi sağlıksız veri olması sebebiyle analizden çıarılmış ve toplam 398 anket ile analizler gerçekleştirilmiştir. 


\subsection{Veri Toplama Araçları}

Araştırmada veri toplama aracı olarak anket uygulamasından yararlanılmıştır. Araştırmada kullanılan anket formu iki ana bölümden oluşmaktadır. Birinci bölümünde öğretmenlerin demografik özelliklerini (cinsiyeti, yaşı, eğitim durumu, çalışma süreleri vb. ) belirlemeye yönelik ifadeler, ikinci bölümde ise öğretmenlerin tükenmişlik ve yaşam tatmin düzeylerini belirlemeye yönelik ifadeler bulunmaktadır. Araştırmada iki ayrı ölçek kullanılmıştır. Öğretmenlerin tükenmişlik düzeylerini belirlemeye yönelik Maslach ve Jackson’ın (1981) geliştirmiş olduğu Tükenmişlik Ölçeği, öğretmenlerin yaşam tatminlerini belirlemeye yönelik ise Diener vd.'nin (1985) geliştirmiş oldukları Yaşam Tatmin Ölçeği kullanılmıştır.

\subsection{Verilerin Analizi}

Verilerin analizinde SPSS 20.0 paket programı kullanılmıştır. Çalışma kapsamında elde edilen verilerin geçerlilik ve güvenirlik analizleri yapılmıştır. Geçerlik için veriler faktör analizine tabi tutulmuştur. Ölçeklerde kullanılan önermelerin güvenirliklerinin belirlenmesi için ise iç tutarlılık aracı olan Cronbach Alfa (a) değeri kullanılmıştır. Daha sonra çalışmanın temel amacı doğrultusunda öncelikleregresyon analizi, daha sonra ikincil amacı olan t testi ve Anova analizi yapılmıştır.

\subsection{Araştırmanın Bulguları}

$\mathrm{Bu}$ başlık altında araştırma kapsamında elde edilen bulgular, katılımcıların demografik özellikleri, ölçeklere yönelik faktör analizleri, t testi ve Anova analizleri yer almaktadır. Demografik değişkenlere ilişkin elde edilen bulgular Tablo 1'de gösterilmiştir. 
Tablo 1: Katılımcıların Demografik Özellikleri

\begin{tabular}{|c|c|c|c|c|c|}
\hline Cinsiyet & $\mathrm{n}$ & $\%$ & Medeni Durum & $\mathbf{n}$ & $\%$ \\
\hline $\begin{array}{l}\text { Erkek } \\
\text { Kadın } \\
\text { Toplam }\end{array}$ & $\begin{array}{l}229 \\
169 \\
398 \\
\end{array}$ & $\begin{array}{c}57,5 \\
42,5 \\
100 \\
\end{array}$ & $\begin{array}{l}\text { Evli } \\
\text { Bekâr } \\
\text { Toplam }\end{array}$ & $\begin{array}{c}335 \\
63 \\
398 \\
\end{array}$ & $\begin{array}{c}84,2 \\
15,8 \\
100\end{array}$ \\
\hline Yaş & $\mathbf{n}$ & $\%$ & Çalışma Saatleri & $\mathbf{n}$ & $\%$ \\
\hline $\begin{array}{l}18-25 \\
26-30 \\
31-35 \\
36-40 \\
41-45 \\
46 \text { ve üzeri } \\
\text { Toplam }\end{array}$ & $\begin{array}{c}14 \\
40 \\
68 \\
106 \\
57 \\
113 \\
398 \\
\end{array}$ & $\begin{array}{c}3,5 \\
10,1 \\
17,1 \\
26,6 \\
14,3 \\
28,4 \\
100\end{array}$ & $\begin{array}{l}6 \text { saatten az } \\
6-8 \text { saat } \\
9-10 \text { saat } \\
11-12 \text { saat } \\
13 \text { ve üzeri saat } \\
\text { Toplam }\end{array}$ & $\begin{array}{c}29 \\
297 \\
52 \\
14 \\
6\end{array}$ & $\begin{array}{c}7,3 \\
74,6 \\
13,1 \\
3,5 \\
1,5\end{array}$ \\
\hline Yöneticilik Görevi & $\mathrm{n}$ & $\%$ & Eğitim & $\mathbf{n}$ & $\%$ \\
\hline $\begin{array}{l}\text { Hayır } \\
\text { Evet } \\
\text { Toplam } \\
\end{array}$ & $\begin{array}{l}272 \\
126 \\
398 \\
\end{array}$ & $\begin{array}{c}68,3 \\
31,7 \\
100 \\
\end{array}$ & $\begin{array}{l}\text { Lisans } \\
\text { Lisansüstü } \\
\text { Toplam }\end{array}$ & $\begin{array}{c}356 \\
42 \\
398 \\
\end{array}$ & $\begin{array}{c}89,4 \\
10,6 \\
100 \\
\end{array}$ \\
\hline Gelir & $\mathbf{n}$ & $\%$ & Çalıșma Yılı & $\mathbf{n}$ & $\%$ \\
\hline $\begin{array}{l}\text { 1500-2000 TL } \\
2001-2500 \mathrm{TL} \\
2501-3000 \mathrm{TL} \\
3001 \text { TL ve üzeri } \\
\text { Toplam }\end{array}$ & $\begin{array}{c}11 \\
91 \\
220 \\
76 \\
398 \\
\end{array}$ & $\begin{array}{c}2,8 \\
22,9 \\
55,3 \\
19,1 \\
100 \\
\end{array}$ & $\begin{array}{l}\text { Bir yildan az } \\
1-5 \text { Y1l } \\
6-10 \\
11 \text { Y1l ve üzeri } \\
\text { Toplam }\end{array}$ & $\begin{array}{c}11 \\
57 \\
58 \\
272 \\
398 \\
\end{array}$ & $\begin{array}{c}2,8 \\
14,3 \\
14,6 \\
68,3 \\
100\end{array}$ \\
\hline Çocuk Sayısı & $\bar{n}$ & $\%$ & Branş & $\bar{n}$ & $\%$ \\
\hline $\begin{array}{l}1 \text { çocuk } \\
2 \text { çocuk } \\
3 \text { ve üzeri çocuk } \\
\text { Çocuğum yok } \\
\text { Toplam }\end{array}$ & $\begin{array}{c}105 \\
179 \\
39 \\
75 \\
398\end{array}$ & $\begin{array}{c}26,4 \\
45,0 \\
9,8 \\
18,8 \\
100\end{array}$ & $\begin{array}{l}\text { Türkçe- Edebiyat } \\
\text { Sosyal Bilgiler } \\
\text { Fen Bilimleri } \\
\text { Matematik } \\
\text { Anaokulu }\end{array}$ & $\begin{array}{l}59 \\
18 \\
28 \\
42 \\
13\end{array}$ & $\begin{array}{c}14,8 \\
4,5 \\
7,0 \\
10,6 \\
3,3\end{array}$ \\
\hline Sosyal Faaliyet Sıklığı & $\bar{n}$ & $\%$ & Yabancı Diller & 36 & 9,0 \\
\hline $\begin{array}{l}\text { Hiç } \\
\text { Çok Nadir } \\
\text { Nadir } \\
\text { Sik } \\
\text { Çok Sık } \\
\text { Toplam }\end{array}$ & $\begin{array}{c}17 \\
53 \\
177 \\
129 \\
22 \\
398\end{array}$ & $\begin{array}{c}4,3 \\
13,3 \\
44,5 \\
32,4 \\
5,5 \\
100\end{array}$ & $\begin{array}{l}\text { Meslek Dersleri } \\
\text { Din Kültürü } \\
\text { Sinıf Ögrretmeni } \\
\text { Diğer } \\
\text { Toplam }\end{array}$ & $\begin{array}{l}49 \\
10 \\
66 \\
77 \\
\\
398\end{array}$ & $\begin{array}{c}12,3 \\
2,5 \\
16,6 \\
19,3\end{array}$ \\
\hline
\end{tabular}

Araştırmaya dahil olan katılımcıların \% 57,5'i erkek, \% 42,5'i bayandır. Katılımcıların medeni durumlarına bakıldığında, \% 84,2'si evli iken, \% 15,8’i bekardır. Katılımcıların \% 26,4'ünün 1 çocuğu, \% 45'inin 2 çocuğu, \% 9,8'inin 3 ve üzeri çocuğu bulunurken, \% 72,8'inin çocuğu yoktur. Katılımcıların \% 3,5'i 18-25 yaş arasında, \% 10,1'i 26-30 yaş arasında, \% 17,1' i 31-35 yaş arasında, \% 26,6'sı 36-40 yaş arasında, \%14,3'ü 41-45 yaş arasında, \% 28,4'ü 46 ve üzeri yaş arasındadır. Katılımcıların \% 7,3'ü 6 saatten az, \% 74,6's1 6-8 saat, \% 13,1'i 9-10 saat, \%3,5'i 11-12 saat ve \% 1,5’i 13 ve üzeri saat çalışmaktadır. Katılımcıların \% 68,3'ü yöneticilik görevi yapmazken, \% 31,7'si yöneticilik görevi yapmıştır. Katılımcıların \% 89,4'ü lisans eğitimine sahipken, \% 10,6'sı lisansüstü eğitime sahiptir. Katılımcıların gelir durumlarına bakıldığında, \% 2,8'i 1500-2000 TL, \% 22,9'u 2001-2500 TL, \% 55,3'ü 2501-3000 TL ve \% 19,1'i 3001 ve üzeri gelire sahiptir. Katılımc1ların \%2,8'i 1 yıldan az, \% 14,3'ü 1-5 y1l, \% 14,6'sı 6-10 y1l ve \% 68,3'ü 11 y1l ve üzeri tecrübeye sahiptir. Katılımcıların mesleki alanlarına bakıldığında, \% 14,8'i Türkçe-Edebiyat, \% 4,5'i Sosyal Bilgiler, \% 7'si Fen Bilimleri, \% 10,6'sı Matematik, \% 3,3'ü anaokulu, \% 9'u Yabancı Diller, \% 12,3'ü Meslek Dersleri, \% 2,5'i Din Kültürü, \%16,6’sı Sınıf Öğretmeni ve \% 19,3’ü diğer branşlarda olduğu görülmektedir. 


\subsection{1. Örnekleme Ait Açıklayıcı İstatistikler}

Tablo 2'de örnekleme ait açıklayıcı istatistikler yer almaktadır.

Tablo 2: Örnekleme Ait açıklayıcı İstatistikler

\begin{tabular}{ccccc} 
& & $\mathbf{n}$ & $\overline{\boldsymbol{X}}$ & Std. S. \\
\cline { 2 - 5 } Tükenmişlik & Duygusal Tükenme & 398 & 2,37 & 0,844 \\
\cline { 2 - 5 } & Kişisel Başarı & 398 & 3,67 & 0,820 \\
\cline { 2 - 5 } & Duyarsızlaşma & 398 & 1,99 & 0,817 \\
\hline Yaşam Doyumu & Yaşam Doyumu & 398 & 3,00 & 0,829 \\
\hline
\end{tabular}




\subsubsection{Geçerlik ve Güvenilirlik Analizi}

Tablo 3: Tükenmişlik Ölçeğinin Faktör Boyutları

\begin{tabular}{|c|c|c|c|c|c|c|}
\hline & & Faktör 1 & Faktör 2 & Faktör 3 & & \\
\hline & & DT & KB & $\mathbf{D}$ & \multirow{3}{*}{$\overline{\boldsymbol{X}}$} & \multirow{3}{*}{$\begin{array}{c}\text { Cronb } \\
\text { ach } \\
\text { Alfa }\end{array}$} \\
\hline & Öz değer & 4,686 & 4,319 & 2,630 & & \\
\hline & $\%$ Varyans & 21,302 & 19,632 & 11,953 & & \\
\hline \multirow{9}{*}{ 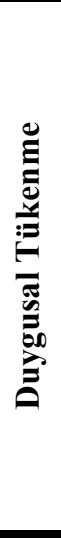 } & İşimin beni hayal kırıklığına uğrattığını hissediyorum & ,757 & & & 2,34 & \multirow{9}{*}{, 877} \\
\hline & $\begin{array}{l}\text { Sabah kalktığımda bir gün } \\
\text { kaldıramayacağımı hissediyorum. }\end{array}$ & ,750 & & & 2,16 & \\
\hline & $\begin{array}{l}\text { Bütün gün öğrencilerle uğraşmak benim için } \\
\text { gerçekten yıpratıcı. }\end{array}$ & ,730 & & & 2,41 & \\
\hline & İşimin beni k1sıtladığını hissediyorum. & ,728 & & & 2,41 & \\
\hline & Tahammülümün sınırına geldiğimi hissediyorum & ,718 & & & 2,29 & \\
\hline & İş gününün sonunda kendimi tükenmiş hissediyorum. & ,708 & & & 2,83 & \\
\hline & İşimden soğuduğumu hissediyorum & ,695 & & & 2,29 & \\
\hline & $\begin{array}{l}\text { Doğrudan doğruya öğrencilerle uğraşmak benim için } \\
\text { stres yaratiyor. }\end{array}$ & ,677 & & & 2,29 & \\
\hline & İşimde çok fazla çalıştığımı hissediyorum.. & ,581 & & & 2,73 & \\
\hline \multirow{7}{*}{ 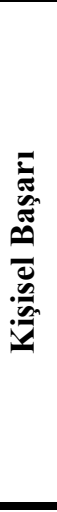 } & Öğrencilerimle ilgilenmekten mutluluk duyarım. & & 823 & & 3,98 & \multirow{7}{*}{, 887} \\
\hline & $\begin{array}{l}\text { Yaptığım iş yoluyla diğer insanların hayatını olumlu } \\
\text { yönde etkilediğimi düşünüyorum. }\end{array}$ & &, 811 & & 3,77 & \\
\hline & $\begin{array}{l}\text { İletişimde bulunduğum insanların ve öğrencilerimin } \\
\text { problemlerini etkin bir biçimde çözebilirim. }\end{array}$ & & ,809 & & 3,62 & \\
\hline & $\begin{array}{l}\text { İşim gereği öğrencilerimle aramda rahat bir ortam } \\
\text { oluşturabilirim }\end{array}$ & & ,808 & & 3,83 & \\
\hline & $\begin{array}{l}\text { Meslek hayatımda kayda değer birçok başarı elde } \\
\text { ettim. }\end{array}$ & & ,710 & & 3,56 & \\
\hline & $\begin{array}{l}\text { İşimde duygusal sorunlara çok serinkanlı bir şekilde } \\
\text { yaklaşırım. }\end{array}$ & & ,706 & & 3,55 & \\
\hline & Kendimi çok enerjik hissediyorum. & & 674 & & 3,38 & \\
\hline \multirow{5}{*}{ 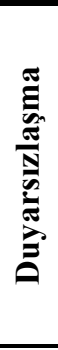 } & $\begin{array}{l}\text { Bu işte çalışmaya başladığımdan beri insanlara karşı } \\
\text { daha da katılaştım. }\end{array}$ & & & ,770 & 2,08 & \multirow{5}{*}{,757 } \\
\hline & Öğrencilere ne olduğu gerçekten umurumda değil. & & & ,719 & $\mathbf{1 , 5 8}$ & \\
\hline & Mesleğim beni duygusal olarak sertleştirdi. & & & 685 & 2,19 & \\
\hline & $\begin{array}{l}\text { Öğrencilerimin bazı problemleri için beni suçladığını } \\
\text { hissediyorum. }\end{array}$ & & & 677 & 2,05 & \\
\hline & $\begin{array}{l}\text { Öğrencilerime bir nesne gibi davrandığımı } \\
\text { hissediyorum. }\end{array}$ & & & ,619 & 2,07 & \\
\hline \multicolumn{5}{|c|}{$\begin{array}{l}\text { Çıkarılan İfade: İşim gereği öğrencilerimin olaylar hakkında ne hissettiğini hemen } \\
\text { anlarım. }\end{array}$} & 3,73 & \\
\hline & & & & $\begin{array}{r}\text { KMO } \\
\text { Barlett's } \\
p\end{array}$ & & $\begin{array}{l}, 850 \\
3811,4 \\
72 \\
, 000\end{array}$ \\
\hline
\end{tabular}


Tablo 4: Yaşam Doyumu Ölçeğinin Faktör Boyutları

\begin{tabular}{|c|c|c|c|c|}
\hline & & Faktör 1 & & \\
\hline & & $\begin{array}{l}\text { Yaşam } \\
\text { Tatmini }\end{array}$ & \multirow{3}{*}{$\overline{\boldsymbol{X}}$} & \multirow{3}{*}{$\begin{array}{l}\text { Cronba } \\
\text { h Alfa }\end{array}$} \\
\hline & Öz değer & 2,632 & & \\
\hline & $\%$ Varyans & 54,638 & & \\
\hline \multirow{8}{*}{ 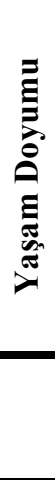 } & $\begin{array}{l}\text { Şimdiye kadar, yaşamdan istediğim önemli şeyleri hemen } \\
\text { hemen elde ettim. }\end{array}$ & ,806 & 3,13 & \multirow{5}{*}{,771 } \\
\hline & Yaşamımdan memnunum. & ,758 & 2,61 & \\
\hline & Yaşam koşullarım mükemmeldir. & ,641 & 3,25 & \\
\hline & $\begin{array}{l}\text { Mevcut hayat tarzım birçok yönden, hayallerimdeki hayat } \\
\text { tarzına yakındır. }\end{array}$ &, 567 & 3,25 & \\
\hline & \multirow[t]{4}{*}{$\begin{array}{l}\text { Eğer hayatımı yeni baştan yaşayabilme imkânım olsaydı, hiçbir } \\
\text { şeyi değiştirmezdim. }\end{array}$} & ,423 & 2,75 & \\
\hline & & & $\mathrm{KMO}$ & ,807 \\
\hline & & & Barlett's & 477,184 \\
\hline & & & $\mathrm{p}$ &, 000 \\
\hline
\end{tabular}

Çalışma kapsamında her iki ölçek ayrı ayrı faktör analizine tabi tutulmuştur. Faktör analizi sırasında döndürme yöntemi olarak "varimax" metodu kullanılmıştır. Faktör analizi ilk olarak tükenmişlik ölçeğine uygulanmıştır. Tükenmişlik ölçeğinde faktör yükü 0,50’in altında kalan 1 önerme dikkate alınmamıştır. Analiz sonucunda tükenmişlik ölçeğinin KMO değerinin 0,85, Barlett's testi sonucunun ise 3811,472 ve anlamlı $(\mathrm{p}=0,000<0,50)$ olduğu görülmüştür. Faktör analizi sonucunda “ duygusal tükenme”, "kişisel başarı”, ve “duyarsızlaşma” olmak üzere üç boyut elde edilmiştir. Elde edilen faktör boyutları Maslach ve Jackson'ın ( 1981) ele almış olduğu tükenmişlik çalışması çalışmamızı destekler niteliktedir. Ayrıca faktör boyutlarına yönelik yapılan güvenirlik analizi sonucunda duygusal tükenme 0,887 , kişisel başarı 0,887 , duyarsılaşma 0,757 şeklindedir.

Yaşam doyumu ölçeğine ilişkin yapılan faktör analizinde, KMO değeri 0,807, Barlett's testi sonucunun ise 477,184 ve anlamlı ( $\mathrm{p}=0,000<0,050)$ olduğu görülmüştür. Tüm önermeler faktör altında olduğu için herhangi bir önermenin çıkarılmasına gerek görülmemiştir. Yaşam doyumu ölçeği tek boyut altında toplanmıştır. Diener vd.'nin (1985) çalışması çalışmamızı destekler niteliktedir.

\subsubsection{Yaşam Doyumu ve Tükenmişlik Düzeyleri Arasındaki İlişsi}

Tablo 5: Korelasyon Analiz Sonuçları

\begin{tabular}{lccccc}
\hline & \multicolumn{1}{c}{ DT } & KB & D & YD \\
\hline Duygusal Tükenme & (DT) & 1 & & & \\
Kişisel Başarı & (KB) &,- 076 & 1 & & \\
Duyarsızlaşma & (D) &, $296 * *$ &,$- 239 * *$ & 1 & \\
Yaşam Doyumu & (YD) &,$- 285^{* *}$ &, $277^{* *}$ &,- 085 & 1 \\
\hline
\end{tabular}

**0,01 anlamlılık düzeyine göre

Faktör analizi sonucu elde edilen boyutlar arasındaki ilişkileri tespit etmek amacıyla korelasyon analizi yapılmıştır. Analiz sonuçlarına göre duygusal tükenme boyutunun, duyarsızlaşma ( $\mathrm{r}=-, 076 ; \mathrm{p}=0,050)$ ile pozitif, yaşam tatmini ( $r=-, 285 ; p=0,050$ ) boyutu ile negatif yönde anlamlı bir ilişki bulunmaktadır. Duygusal tükenme ile kişisel başarı boyutu arasında anlamlı bir ilişki tespit edilememiştir. Kişisel başarı boyutunun ise 
duyarsızlaşma $(r=-, 239 ; p=0,050)$ boyutu ile negatif yönde, yaşam doyumu ile $(r=, 277 ; p=0,050)$ pozitif yönde anlamlı bir ilişskisi bulunmaktadır.

\subsubsection{Tükenmişliğin Yaşam Doyumu Üzerindeki Etkisi}

Tükenmişliğin yaşam doyumu üzerindeki etkisini belirlemeye yönelik regresyon analizi yapılmıştır.

Tablo 6: Tükenmişliğin Yaşam Doyumu Üzerindeki Etkisi

\begin{tabular}{|c|c|c|c|c|c|}
\hline $\begin{array}{c}\text { Bağımsız } \\
\text { Değişkenler }\end{array}$ & $\boldsymbol{\beta}$ & $\mathbf{t}$ & $\mathbf{R}^{2}$ & $\mathbf{F}$ & $\begin{array}{c}\text { F değerinin } \\
\text { anlamlılık } \\
\text { Düzeyi }\end{array}$ \\
\hline Duygusal Tükenme &,- 283 & $-5,813^{*}$ & \multirow{3}{*}{143} & \multirow{3}{*}{23,162} & \multirow{3}{*}{0,000} \\
\hline Kişisel Başarı &, 270 & $5,650 *$ & & & \\
\hline Duyarsızlaşma &, 063 & 1,262 & & & \\
\hline
\end{tabular}

Tükenmişliğin yaşam doyumu üzerindeki etkisini belirlemeye yönelik gerçekleştirilen regresyon analizi sonuçlarına göre; duygusal tükenme eğilimi, yaşam doyumunu $(\beta=-, 283 ; p=, 000<, 05)$ negatif yönde, kişisel başarı eğilimi, yaşam doyumunu $(\beta=, 270 ; p=, 000<, 05)$ pozitif yönde anlamlı bir şekilde etkilemektedir. Öğretmenlerin yaşam doyum düzeyleri artıkça duygusal tükenme eğilimleri azalırken, kişisel başarı durumları ise artmaktadır. Yapılan regresyon analizi sonucunda yaşam doyumunun duyarsızlaşma üzerinde anlamı bir etkiye sahip olmadığı görülmektedir.

\subsubsection{Demografik Değișkenlerin Tükenmișlik ve Yaşam Doyumundaki Rolü}

Demografik değişkenlere göre öğretmenlerin tükenmişlik düzeyleri ve yaşam tatminlerin farklılaşıp farklılaşmadığını belirlemek amacıyla t testi yapılmış ve istatiksel sonuçlar Tablo 6'da verilmiştir.

Tablo 7: Cinsiyete Göre Tükenmişlik ve İş ve Yaşam Doyumu T Testi Analiz Bulguları

\begin{tabular}{|c|c|c|c|c|c|c|}
\hline Tükenmişlik & $\begin{array}{l}\text { Medeni } \\
\text { Durum }\end{array}$ & A.O & S.S & $\begin{array}{c}\text { Levene } \\
\text { (F) }\end{array}$ & $\mathbf{t}$ & $\mathbf{p}$ \\
\hline \multirow{2}{*}{$\begin{array}{l}\text { Duygusal } \\
\text { Emek }\end{array}$} & Erkek & 2,30 &, 852 & \multirow{2}{*}{1,102} & \multirow{2}{*}{$-1,827$} & \multirow{2}{*}{$0,06 \mathrm{C}$} \\
\hline & Kadın & 2,46 &, 828 & & & \\
\hline \multirow{2}{*}{ Kişisel Başarı } & Erkek & 3,66 & , 886 & \multirow{2}{*}{8,327} & \multirow{2}{*}{,- 263} & \multirow{2}{*}{0,792} \\
\hline & Kadın & 3,68 &, 723 & & & \\
\hline \multirow{2}{*}{ Duyarsızlaşma } & Erkek & 2,06 &, 849 & \multirow{2}{*}{1,870} & \multirow{2}{*}{2,020} & \multirow{2}{*}{0,044} \\
\hline & Kadın & 1,90 & ,764 & & & \\
\hline \multirow{2}{*}{$\begin{array}{l}\text { Yaşam } \\
\text { Tatmini }\end{array}$} & Erkek & 2,96 &, 821 & \multirow{2}{*}{, 161} & \multirow{2}{*}{$-1,028$} & \multirow{2}{*}{0,305} \\
\hline & Kadın & 3,05 & ,839 & & & \\
\hline
\end{tabular}

Öğretmenlerin tükenmişlik düzeyleri ve yaşam tatmin düzeyleri cinsiyet değişkeni ile $\mathrm{t}$ testine tabi tutulmuştur. Tablo 7'de görüldüğü gibi yapılan analiz sonucunda, tükenmişlik boyutlarından duyarsızlaşma eğilimleri $(p=0,044<0,050)$ cinsiyet değişkenine göre anlamlı bir farklılık göstermektedir. Erkek öğretmenlerin, kadın öğretmenlere göre mesleklerine karşı duyarsızlaşma eğilimlerinin daha yüksek olduğu görülmüştür. Cinsiyete göre diğer boyutlar anlamlı bir farklılık göstermemektedir. Yapılan t testi analiz sonuçlarında medeni durum değişkeni, yöneticilik görevinde bulunma değişkeni ve kadro türü değişkeni ile yapılan t testi sonuçlarında anlamlı bir farklılık görülmemiştir. 


\subsubsection{Anova Analizi}

Tablo 8: Sosyal Faaliyet Sıklığına Göre Duyarsızlaşma Eğilimi Varyans Bulguları

\begin{tabular}{|c|c|c|c|c|c|c|c|c|}
\hline $\begin{array}{c}\text { Sosyal Faaliyet } \\
\text { Sıklığı (SFS) }\end{array}$ & $\mathbf{N}$ & $\bar{X}$ & S.S & $\mathbf{F}$ & $\mathbf{p}$ & & \multicolumn{2}{|c|}{$\begin{array}{c}\text { Ortalamaların } \\
\text { Farklılığı }\end{array}$} \\
\hline Hiç & 17 & 2,52 & ,96 & \multirow{6}{*}{3,240} & \multirow{5}{*}{,012 } & & & \\
\hline Çok Nadir & 53 & 1,96 &, 83 & & & & SFS & I-J \\
\hline Sık & 177 & 1,89 &, 73 & & & \multirow{2}{*}{ Hiç } & Çok Nadir & ,567 \\
\hline Nadir & 129 & 2,10 & ,89 & & & & Nadir & 632 \\
\hline Çok Sık & 22 & 1,86 &, 65 & & & & S1k & 427 \\
\hline Toplam & 398 & 1,99 &, 81 & & & & Çok sık &, $665^{*}$ \\
\hline
\end{tabular}

Tablo 8'de görüldüğü gibi öğretmenlerin sosyal faaliyetlere katılma sıklığı ile tükenmişlik boyutlarından duyarsızlaşma eğilimi arasında anlamlı bir farklılık görülmektedir $(F=3,240 ; p=0,012<0,050)$. $B u$ bağlamda, sosyal faaliyet durumu "hiç" $(\overline{\boldsymbol{X}}=2,52 ; \mathrm{S} . \mathrm{S}=, 96)$, olan öğretmenlerin duyarsızlaşma eğilimleri daha yüksektir. Ayrıca sosyal faaliyet durumları "çok sık" $(\overline{\boldsymbol{X}}=1,86$; S.S $=, 65)$, olan öğretmenlerin duyarsızlaşma eğilimleri diğer katılma durumlarına göre daha azdır.

\section{SONUÇ VE ÖNERILLER}

Ülkemizde öğretmenlerin tükenmişlik düzeyleri ile ilgili yapılan çalışmaların sınırlı olduğu görülmektedir. Eğitimin önemi ve niteliği açısından öğretmenlerde tükenmişlik düzeylerinin belirlenmesi ve buna bağlı olarak yaşam doyumlarının belirlenmesi araştırmanın önemini ortaya koymaktadır. Bu çalışmada elde edilen bulgular 1şı̆̆ında öğretmenlerin tükenmişlik düzeylerinin yaşam doyumları üzerindeki etkisi araştırılmıştır. Elde edilen veriler neticesinde öğretmenlerin tükenmişlik düzeyleri “ duyusal tükenme”, "kişisel başarı" ve "duyarsızlaşma" olmak üzere üç boyut altında toplanmıştır. Yaşam doyumu ise tek boyut altında incelenmiştir. Çalışma kapsamında elde edilen bulgular sonucunda öğretmenlerin duygusal tükenme ve duyarsızlaşma eğilimlerin düşük olduğu, kişisel başarı eğilimlerinin ise ortalamanın üzerinde biraz yüksek olduğu görülmektedir. Yaşam doyumlarının ise orta düzeyde olduğu görülmektedir. Öğretmenlik mesleğinin öğretmenleri hayal kırıklığına uğratmaması, öğrencilerle sürekli olarak ilgilenmelerinin öğretmenleri olumsuz etkilememesi, mesleklerinin hayatlarını kısıtlamaması, iş günü sonunda kendilerini tükenmiş hissetmemeleri, işlerinden soğumamaları vb. faktörler ise öğretmenlerin duygusal olarak daha pozitif olmalarını sağlamakta ve tükenmişlik boyutlarından olan duygusal tükenme eğilimini daha az yaşamalarını sağlamaktadırlar. Öğretmenlerin duygusal olarak tükenmişlik sergilememeleri eğitim camiası adına çok önemli bir faktördür. Çünkü toplum olarak ayakta kalabilmek, toplum olarak ilerleyebilmek ve gelecek nesillere daha iyi yaşam koşulları sunabilmek adına eğitimin anahtar rolünü oynayan öğretmenlere ihtiyacımız vardır. Öğretmenler, bir toplumu yetiştiren ve o topluma yön veren önemli kişilerdir. Bu bakımdan çalışma kapsamında elde edilen bulgular sonucunda öğretmenlerin duygusal tükenme eğilimlerinin düşük olduğu görülmüştür.

Öğretmenlerin öğrencileri ile ilgilenmekten mutluluk duyması, yaptıkları işi dolayısıyla hayatlarının olumlu etkilenmesi, öğrencilerin sorunlarının etkin bir biçimde çözümlemeleri, işi gereği öğrencileri ile rahat bir ortam oluşturması, meslek hayatlarında kayda değer birçok başarı elde etmesi ve duygusal sorunlara serinkanlılıkla yaklaşmaları, öğretmenlerin kişisel başarı eğilimleri artıran önemli faktörler olarak ön plana 
çıkmaktadır. Çalışma kapsamında elde edilen bulgular sonucunda öğretmenlerin tükenmişlik boyutlarında olan kişisel başarı eğilimlerinin ortalamanın üzerinde biraz yüksek olduğu görülmüştür. Öğretmenlerin meslek hayatlarına başladıktan sonra insanlara karşı duyarsızlaşmaması, mesleki olarak katılaşmaması, öğrencilerin sorunları ile ilgilenmesi ve öğrencilere karşı hassasiyet göstermeleri vb. faktörler ise duyarsızlaşma eğilimlerini ifade eden faktörler olarak ön plana çıkmaktadır. Çalışma kapsamında öğretmenlerin duyarsızlaşma eğilimlerinin düşük olduğu görülmüştür. Elde edilen bu sonuç da eğitim camiası açısından önemli bir bulgudur. Çünkü mesleklerine bağl1 ve mesleklerinin zorluğuna karşı duyarsızlaşma eğilimi göstermeyen öğretmenlerin toplumumuza 1şık tutacakları aşikârdır. Öğretmenlerin yaşamdan istedikleri önemli şeyleri elde etmeleri, yaşam koşullarının iyi olması ve yaşamlarından memnun olması, mevcut hayat tarzlarının hayallerindeki hayat tarzına yakın olması ve hayatlarında var olan düzenleri değiştirmek istememeleri ise yaşam doyumlarını etkileyen faktörler olarak ön plana çıkmaktadırlar. Yapılan çalışmada öğretmenlerin yaşam doyumlarının orta düzeyde olduğu görülmektedir. Toplum adına önemli bir mesleği ifa eden öğretmenlerin yaşam doyumlarının daha yüksek olması arzu edilen bir durum olarak önem arz etmektedir.

Çalışma kapsamında öğretmenlerin tükenmiş düzeyleri ile yaşam doyumu arasındaki ilişkisi belirlemek üzere korelasyon analizi gerçekleştirilmiştir. Analiz sonucunda duygusal tükenme ve duyarsızlaşma eğilimi ile yaşam doyumu arasında negatif, kişisel başarı eğilimi ile yaşam doyumu arasında ise pozitif yönde bir ilişki olduğu sonucuna ulaşılmıştır. Öğretmenlerin tükenmişlik düzeylerinin yaşam doyumları üzerindeki etkisini belirlemeye yönelik regresyon analizi gerçekleştirilmiştir. Analiz sonucunda tükenmişliğin yaşam doyumu üzerinde \% 0,146’lık bir etkiye sahip olduğu görülmektedir. Duygusal tükenme ve duyarsızlaşma eğilimi, yaşam doyumu negatif yönde, kişisel başarı eğilimini ise pozitif yönde etkilemektedir.

Çalışma kapsamında demografik özelliklere yönelik t testi ve Anova analizleri yapılmıştır. Analiz sonuçlarında demografik değişkenlerden cinsiyet değiş̧eni ve sosyal faaliyetlere katılma dereceleri değişkeni ile anlamlı ilişkiler bulunmuştur. Diğer demografik değişkenlere yönelik anlamlı ilişkiler tespit edilememiştir. Cinsiyet faktörünün ise tükenmişlik boyutlarından sadece duyarsızlaşma eğilimi ile anlamlı bir farklılık göstermektedir. Erkek öğretmenlerin kadın öğretmenlere oranla çok az bir fark olmasına rağmen daha fazla duyarsızlaşma eğilimleri gösterdikleri sonucuna ulaşılmıştır. Literatür kapsamında tükenmişlik ile ilgili yapılan çalışmalarda; öğretmenlerde tükenmişlik Friedman (1991), öğretim elemanlarında tükenmişlik Tümkaya (1997), sağlık çalışanlarında tükenmişlik Karlıdağ vd. (2000), cinsiyet değişkeni ile tükenmişlik arasında anlamlı farklılıklara rastlanmıştır. Erkeklerin bayanlara göre daha fazla tükenmişlik yaşadıkları ifade edilmektedir. Girgin ve Baysal (2005), Sürgevil (2005), Otacıŏglu (2008) çalışmalarında kadın ve erkeklerin tükenmişlik düzeylerinin farklı olduğu tespit edilmiştir. Bunun nedeni olarak kadın ve erkeklerin kişilik yapılarının farklılığı, çalışma ortamları ve özel hayattaki rolleri sebep olarak gösterilmektedir. Dolunay (2002) çalışmasında çalışanların yaş değişkeni ile tükenmişlik düzeyleri arasında anlamlı farklılıklar bulunmaktadır. Çalışanların yaş düzeyleri arttıkça duygusal tükenme ve duyarsızlaşma eğilimlerinin azaldığı ve kişisel başarı eğilimlerinin arttığı görülmüştür. Güdük (2008) çalışmasında ise bireylerin yaş düzeyleri arttıkça duygusal tükenme eğilimlerin arttığı fakat kişisel başarı ve duyarsızlaşa eğilimi ile herhangi bir anlamlı farklılığın olmadığı sonucuna ulaşılmıştır. Bu çalışma da öğretmenlerin yaşları ile tükenmişlik düzeyleri arasında anlamlı farklılıklara rastlanmamıştır. Öğretmenlerin branşları ile tükenmişlik düzeyleri arasında anlamlı farklıklara rastlanan çalışmalar bulunmaktadır (Tümkaya, 1996; Izgar, 2001; Gençer, 2002; Gündüz, 2004; Şahin 2007). Bu çalışmada öğretmenlerin branşları ile ilgili herhangi bir farklılığa rastlanmamıştır. Sosyal faaliyetlere katılma 
derecelerine göre yapılan Anova analizi sonucunda ise sosyal faaliyetlere hiç katılmayan öğretmenlerin duyarsızlaşma eğilimlerinin yüksek olduğu görülmüştür.

Sonuç olarak öğretmenlerin tükenmişlik boyutlarından duygusal tükenme ve duyarsızlaşma eğilimlerin düşük ve kişisel başarı eğilimlerin ortalamanın üzerinde olduğu görülmüştür Ayrıca öğretmenlerin yaşam doyumların orta düzeyde olduğu görülmüştür. Öğretmenlerin tükenmişlik düzeyleri ve yaşam doyumları önemli konulardır. Bu bakımdan öğretmenlerin yaşam doyumların artırılması gerekmektedir. Ayrıca tükenmişliğe neden olacak faktörlerin önceden belirlenmesi ve bu konuda gerekli tedbirlerin alınması gerekmektedir.

\section{KAYNAKÇA}

Altay, Birsen, Gönener, Demet ve Demirkıran, Ceren (2010), "Bir Üniversite Hastanesinde Çalışan Hemşirelerin Tükenmişlik Düzeyleri ve Aile Desteğinin Etkisi”, Fırat Tıp Dergisi, Cilt.15 No. 1, (10-16).

Ardıç, Kadir ve Polatçı, Sema (2009), “Tükenmişlik Sendromu ve Madalyonun Öbür Yüzü: İşle Bütünleşme”, Erciyes Üniversitesi İktisadi ve İdari Bilimler Fakültesi Dergisi, No. 32, (21-46).

Arı, Sağlam, Güler ve Bal, Çına, Emine (2008) “Tükenmişlik Kavramı: Birey ve Örgütler Açısından Önemi”, Yönetim ve Ekonomi: Celal Bayar Üniversitesi İktisadi ve İdari Bilimler Fakültesi Dergisi, Cilt.15, No.1, (131-148).

Avşaroğlu, Selahatttin, Deniz, Engin, M. ve Kahraman, Ali (2005), “Teknik Öğretmenlerde Yaşam Doyumu, İş Doyumu ve Mesleki Tükenmişlik Düzeylerinin İncelenmesi”, Selçuk Üniversitesi Sosyal Bilimler Enstitüsü Dergisi, No. 14, (115-129).

Baş, Türker (2006) Anket, Ankara, Seçkin Yayıncılık.

Cecen-Eroğul, Rezan, Ayşe ve Dingiltepe, Timır (2012), "Parçalanmış ve Tam Aileye Sahip Ergenlerin Yaşam Doyumu Düzeyleri ile Yaşam Kalite Düzeylerinin Karşılaştırılması” İlköğretim Online, Cilt.11 No.4, (1077-1086).

Cemaloğlu, Necati ve Şahin, Erdemoğlu, Dilek (2007), “Öğretmenlerin Mesleki Tükenmişlik Düzeylerinin Farklı Değişkenlere Göre İncelenmesi”, Kastamonu Ĕ̆itim Dergisi, Cilt.15, No.2, (465-484).

Ceyhan, Aydoğan Aykut ve Siliğ Aylin (2005), "Banka Çalışanlarının Tükenmişlik Düzeyleri ile Uyum Düzeyleri Arasındaki İlişkiler”, Anadolu Üniversitesi Sosyal Bilimler Dergisi, Cilt.5, Sayı.2, (43-56).

Cordes, Cynthia. L. Dougherty, Thomas, W. and Blum, Michael (1997), "Patterns of Burnout Among Managers and Professionals: A Comparison of Models", Journal of Organizational Behavior, Vol.18, Issue.6, $(685-701)$.

Dikmen, Alpay, Ahmet (1995), “İş Doyumu ve Yaşam Doyumu İlişkisi”. Ankara Üniversitesi SBF Dergisi, Cilt.50, No.03, (115-140).

Dolunay, Birsen, Ayşe (2002), "Keçiören İlçesi Genel Liseler ve Teknik-Ticaret-Meslek Liselerinde Görevli Öğretmenlerde Tükenmişlik Durumu Araştırması”, Ankara Üniversitesi Tıp Fakültesi Mecmuası, Cilt.55 No.01, (51-62).

Eğinli, Temel, Ayşen (2009), “Çalışanlarda İş Doyumu: Kamu ve Özel Sektör Çalışanlarının İş Doyumuna Yönelik Bir Araştırma”, Atatürk Üniversitesi İktisadi ve İdari Bilimler Dergisi, Cilt.23, No.3, (35-52).

Ergin, Canan (1992), "Doktor ve Hemşirelerde Tükenmişlik ve Maslach Tükenmişlik Ölçeğinin Uyarlanması”, VII. Ulusal Psikoloji Kongresi Bilimsel Çalışmaları, $(22,25)$. 
Eroğul Çeçen, Rezan, A. ve Örkün, Ümran (2012), “Tekstil Sektörü Mavi Yaka Çalışanlarının Yaşam Doyumu ve Tükenmişlik Düzeylerinin İş Doyumu Tarafından Yordanması” Çukurova Üniversitesi Sosyal Bilimler Enstitüsü Dergisi, Cilt.21, No.1, (323-338).

Ertürk, Emel ve Keçecioğlu, Tamer (2012), “Çalışanların İş Doyumları ile Mesleki Tükenmişlik Düzeyleri Arasındaki İlişkiler: Öğretmenler Üzerine Örnek Bir Uygulama”, Ege Akademik Bakış, Cilt.12, No.1, (39-52).

Freudenberger, Herbert. J. (1974), “Staff Burn-Out”, Journal of Social İssues, Vol.30, Issue.1, (159-165).

Güdük, Mehmet, Erol, Şerafettin., Yağcıbulut, Özcan., Uğur, Zeynep, Özvarış, Şevkat, Bahar ve Aslan, Dilek (2005), “Ankara'da Bir Tıp Fakültesinde Okuyan Son Sınıf Öğrencilerde Tükenmişlik Sendromu”, Sürekli Tıp Ë̆itimi Dergisi, Cilt.14, No.8, (169-173).

Güllüce, Çağlar, Ali, İşcan, Faruk, Ömer (2010), "Mesleki Tükenmişlik ve Duygusal Zekâ Arasındaki İlişki”, Eskişehir Osmangazi Üniversitesi İ̈BF Dergisi, Cilt.5, No.2, (7-29).

Kayabaşı, Yücel (2008) “Bazı Değişkenler Açısından Öğretmenlerin Mesleki Tükenmişlik Düzeyleri”, Sosyal Bilimler Dergisi, No.20, (191-212).

Kılıç, Taşkın ve Seymen, Ayten, Oya (2011), "Sağlık Sektöründe, Tükenmişlik Sendromuna Etki Eden Faktörlerin Analizi ve Bir Araştırma” Yönetim ve Ekonomi Araştırmaları Dergisi, No.16, (47-67).

Maraşlı, Müge (2005), “Bazı Özelliklerine ve Öğrenilmiş Güçlülük Düzeylerine Göre Lise Öğretmenlerinin Tükenmişlik Düzeyleri”, Türk Tabipler Birliği Mesleki Să̆llk ve Güvenlik Dergisi, Cilt.23, No.3, (2733).

Maslach, Christina, ve Jackson, Susan E. (1981), “The Measurement of Experienced Burnout”, Journal of Organizational Behavior, Vol.2, Issue.2, (99-113).

Maslach, Christina, Schaufel1, Wilmar. B., and Leiter, Michael, P. (2001), "Job Burnout", Annual Review of Psychology, Vol.52, Issue.1, (397-422).

Okutan, Elvan, Yıldız, Şule ve Konuk, Filiz (2013), "İş Hayatında Tükenmişlik Sendromu: Finans ve Muhasebe Çalışanlarının Tükenmişlik Düzeylerinin Belirlenmesine İlişkin Bir Çalışma", Çankırı Karatekin Üniversitesi İktisadi ve İdari Bilimler Fakültesi Dergisi, Cilt.3, No.2, (1-17).

Oruç, Serap (2007), Özel Eğitim Alanında Çalışan Öğretmenlerin Tükenmişlik Düzeylerinin Bazı Değişkenler Açısından İncelenmesi (Adana İli Örneği), Çukurova Üniversitesi, Yüksek Lisans Tezi. Adana.

Örkün, Ümran (2011), Tekstil Sektörü Mavi Yaka Çalışanlarının Yaşam Doyumu ve Tükenmişlik Düzeylerinin Işs Doyumu Tarafindan Yordanması, Çukurova Üniversitesi, Sosyal Bilimler Enstitüsü, Yayımlanmamış Yüksek Lisans Tezi.

Pavot, William, and Diener, Ed (1993), "Review of the Satisfaction With Life Scale", Psychologic Alassessment, Vol.5, Issue.2, (164-172).

Telef, Baki, Bülent (2011), “The Study of Teachers' Self-Efficacy, Job Satisfaction, Life Satisfaction and Burnout", Elementary Education Online, Vol.10, Issue.1, (91-108).

Ünal, Süheyla, Karlıdağ, Rıfat, ve Yoloğlu, Saim (2001), “Hekimlerde Tükenmişlik ve İş Doyumu Düzeylerinin Yaşam Doyumu Düzeyleri ile İlişkisi”, Klinik Psikiyatri, Cilt.4, No.2, (113-118).

Wright, Thomas. A. and Bonett, Douglas, G. (1997), "Research the Contribution of Burnout to Note Work Performance”, Journal of Organizational Behavior, Issue.18, (491-499). 
Yılmaz, Ercan ve Sünbül, Ali, Murat (2009), “Öğretmenlerin Yaşam Doyumları ve Okullardaki Örgütsel Güven Düzeyi”, Journal of Qafqaz University, Issue.26, (172-179).

Yılmaz, Gözde, Keser, Aşkın, ve Yorgun, Sayım (2010), "Konaklama İşletmelerinde Çalışan Sendika Üyelerinin İş ve Yaşam Doyumunu Belirlemeye Yönelik Bir Alan Araştırması", Paradoks Ekonomi, Sosyoloji ve Politika Dergisi, Cilt.6, No.1, (87-107). 